Митыпова Г. С. Образовательная среда и развитие подрастающего поколения в условиях секулярного общества (по материалам региональных Рождественских чтений «К 350-летию со дня рождения Петра I: секулярный мир и религиозность»)

Научная статья

УДК 316.346:2

DOI: $10.18101 / 2305-753 X-2021-4-33-38$

\title{
ОБРАЗОВАТЕЛЬНАЯ СРЕДА И РАЗВИТИЕ \\ ПОДРАСТАЮЩЕГО ПОКОЛЕНИЯ \\ В УСЛОВИЯХ СЕКУЛЯРНОГО ОБЩЕСТВА \\ (по материалам региональных Рождественских чтений \\ «К 350-летию со дня рождения Петра I: секулярный мир и религиозность»)
}

\author{
(C) Митыпова Гунсема Сандаковна \\ доктор исторических наук, доцент, \\ Бурятский республиканский институт образовательной политики \\ Россия, 670000, г. Улан-Удэ, ул. Советская, 30 \\ gunsema53@mail.ru
}

\begin{abstract}
Аннотация. В статье рассмотрены основополагающие вопросы духовнонравственного воспитания в образовательной среде в контексте развития подрастающего поколения в условиях секулярного общества. Автор в статье поддерживает позицию иерархов Церкви в том, что сегодня изменился мир и человек, ценностная ориентация которой направлена в основном на потребление материальных благ. Объединение усилий в современном секулярном мире духовенства, родительской и учительской общественности, позволит развитию и формированию у современных детей четких нравственных критериев и ориентиров. Учительская общественность ставит в своей повседневной деятельности задачи необходимости объединения обучения и воспитания в целостный образовательный процесс на основе духовнонравственных и социокультурных ценностей народов России.

Ключевые слова: епископ, учитель школа, образование, среда, воспитание, религиозная культура, секулярный мир, империя, общество, поколение.
\end{abstract}

\section{Для цитирования}

Muтыпова Г. С. Образовательная среда и развитие подрастающего поколения в условиях секулярного общества (по материалам региональных Рождественских чтений «К 350-летию со дня рождения Петра I: секулярный мир и религиозность») // Вестник Бурятского государственного университета. Гуманитарные исследования Внутренней Азии. 2021. Вып. 4. С. 33-38.

Сегодня обращается особое внимание на формирование и развитие подрастающего поколения нашей страны, в связи с чем в рамках региональных Рождественских чтений в ноябре 2021 г. получили возможность обсудить актуальные вопросы духовно-нравственного воспитания подрастающего поколения в урочной и внеурочной деятельности педагогов, о взаимодействии школы с религиозными организациями, в данном случае с православной церковью, с деятелями православия.

В выступлении Николая (Кривенко), епископа Северобайкальского и Сосново-Озерского прозвучало следующее: «Нынешний конфликт религиозной и секулярной систем является не только теоретическим противоречием и столкновением религиозного и светского разума, но он просто неразрывно связан с историей, культурой и цивилизационными особенностями различных слоев че- 
ловечества, призванных к мирному сосуществованию в современных условиях. Разобраться в этом помогает знание нашей истории».

Действительно, история Восточной Сибири, становление российской государственности на востоке страны во многом связано с именем Петра I. Об исторических фактах, касающихся современной Бурятии затронул в своем выступлении и ректор БРИОП В. Цыренов: «...на формирование российской государственности в этой части страны оказало влияние 5 факторов, и многие исторические вопросы связаны с историей развития Бурятии:

1. Дипломатические миссии - Нерчинский договор. 6 сентября (27 августа) 1689 года был подписан Нерчинский договор - первый мирный договор между Россией и Китаем, важнейшая историческая роль которого заключается в том, что он впервые определил и государственную границу между двумя странами.

Федор Головин - представитель Посольского приказа, на тот момент имел дворянский титул окольничего. Впоследствии - один из ближайших сподвижников Петра Великого, первый в истории России генерал-фельдмаршал. Возглавлял дипломатическую миссию при подписании Нерчинского договора.

Здесь же надо отметить, что встрече хори бурят с Петром I немалую роль сыграл Федор Головин, который непосредственно был в наших краях при подписании Нерчинского договора.

2. Делегация хори бурят к Петру в 1702-1703 гг. и Указ Петра Великого о породных землях родов и племен. «... на породные свои земли кочевать, где жили прадеды и деды и отцы их, и после де их и иные роды их вышли въ нашъ Великаго Государя ясашной платежъ; а породные ихъ земли кочевныя места по Селенге, по Уде и по Курбе рекам; на техъ де ихъ кочевных местах Удинские казаки многие заимками поселились по правую сторону ниже Чикою реки Хилку, по Тугную, по Уде и по Итанце подле Байкала моря по правую же сторону Селенги реки Кударинская степь...» ${ }^{1}$.

3. Буринский договор 1727 г. и Савва Рагузинский. Заключенные между Россией и Китаем договоры - Буринский 1727 и Кяхтинский 1727 гг. - не только определили на долгие годы мирные взаимоотношения между странамисоседями, но и стали судьбоносными для России и Китая, сделав Кяхту главным центром русско-китайской торговли. Кяхта (Троицкосавск) в начале XVIII первой половине $\mathrm{XX}$ вв. являлся не только торговым городом, соединившим Россию и Китай.

4. Православные миссии, устройство Св. Троицкого Селенгинского и СпасоПреображенского монастырей на восточном побережье Байкала. Распространение православия на территории современной Бурятии исторически связана с процессом присоединения территории Байкальского региона России с семнадцатого века в Сибири, как одного из субъектов и территорий Сибири в составе Российского государства.

\footnotetext{
${ }^{1}$ Указ Петра Великого (март 1703 г.) // Материалы Комиссии Куломзина. Вып. V, приложение 22. Санкт-Петербург, 1898. Текст: непосредственный.
} 
Митыпова Г. С. Образовательная среда и развитие подрастающего поколения в условиях секулярного общества (по материалам региональных Рождественских чтений «К 350-летию со дня рождения Петра I: секулярный мир и религиозность»)

5. Географические и академические экспедиции в страны Центральной Азии, на Дальний Восток и Аляску. История продвижения России в глубь Сибири, на Дальний Восток и Аляску является значительной частью истории страны, а православная миссия имеет также свои страницы.

Безусловно, существует и другое множество событий, которые предопределили именно такой ход исторического развития нашего региона. Они требуют исследования и осмысления нами». В своем выступлении В. Ц. Цыренов отметил важное значение исторических событий, определил задачи педагогов всех уровней обращение к истокам процесса формирования российской государственности на востоке страны.

Приведем некоторые выступления педагогов региона, которые поделились опытом работы, о проблемах, которые возникают в практической деятельности. В докладе М. С. Мухиной,учителя музыки и мировой художественной культуры, находят отражение вопросы, которые раскрывают вопросы культуры народа, проводятся беседы «Береги землю родимую, как мать родимую» и «Жизнь ратными подвигами полна» позволяет педагогу выполнить проекты, рассказывающие о подвиге воинов-земляков в годы Великой Отечественной войны и провести урок не в обычной классной аудитории, а в школьном музее или в новом сквере, где сооружены памятники (Дети войны (установлен в 2019 г.) и обелиск Воинам-землякам (отреставрирован в 2021 г.)).

При изучении темы «Культурное наследие христианской Руси» учителем реализовываются проекты, раскрывающие содержание престольных праздников, организуются экскурсию в православный храм села Шигаево. При изучении темы «Величие многонациональной российской культуры» она пишет, что говорим не только о российских, но и бурятских деятелях науки и культуры. В рамках уроков применяются различные методы, например, метод образного видения, раскрываются понятия добра и зла, любовь к ближнему, почтительное отношение к старшим, любовь к Родине, уважительное отношении к ее истории и культуре - вот темы, затрагиваемые на уроках и вне уроков. В выступлении Е. Е. Рыбаковой из Нижнеангарской школы получило отражение использование игровых технологий на уроках ОРКСЭ, не менее интересны выступления коллег - М. В. Бузиной, где поднимались теоретические и практические вопросы самоценности, понятия о добре, о некоторой агрессивности в поведении школьников, М. П. Поповой, педагога Заиграевского Дома детского творчества, которую интересует вопрос о социальном статусе современной семьи, вызвало неподдельный интерес выступление учителя истории Талецкой школы А. Ю. Леонова, который вводит в канву урока неизвестные архивные документы по истории Верхнеудинского уезда, о дореволюционной школе, доклад Т. А. Цыреновой, учителя литературы из «Лингвистической гимназии № 3 г. Улан-Удэ», «Нравственные искания героев рассказов А. П. Чехова» позволил по-новому взглянуть на сюжеты литературных произведений. Т. Н. Перякина, педагог «Республиканского центра образования», поделилась опытом преподавания основ светской этики учащимся с ОВ3 дистанционно: проблемы, идеи, решения. О необходимости объединению обучения и воспитания в целостный образовательный процесс на основе духовнонравственных и социокультурных ценностей прозвучало в докладе Е. И. Зубакиной, учителя Ново-Горхонской школы. 
Темы выступлений посвящены: особенностям организации и реализации образовательной и воспитательной деятельности обучающихся на разных ступенях образования; связи духовно-нравственного воспитания в школе с национальными ценностями; особенностям организации учебных курсов и курсов внеурочной деятельности по вопросам духовно-нравственного воспитания школьников в начальной и основной школе; обсуждению проектов, моделей, успешных практик педагогов, творческих коллективов и образовательных организаций по реализации духовно-нравственного воспитания детей и молодежи; реализации моделей введения предметной области «Основы духовно-нравственной культуры народов России» (ОДНКНР) в системе общего образования Республики Бурятия; методике преподавания учебного курса «Основы религиозных культур и светской этики»; объединению обучения и воспитания в целостный образовательный процесс на основе духовно-нравственных и социокультурных ценностей; рассмотрению этнокультурных аспектов реализации воспитательной деятельности образовательных организаций, как условие сохранения духовно-нравственного наследия.

Надо согласиться с мнением иерархов Церкви, что «Сегодня наше общество оказалось в не менее сложном положении, чем в период правления Петра I, а может быть даже более сложном, жизнь которого определяется системой ценностей, порожденной не религиозным, а секулярным мировоззрением и его многочисленным воинствующим проявлением. Секулярные взгляды также предполагали высокое призвание человека, которое состояло в максимальной реализации его творческой способности осваивать и преображать безбожный мир. Однако сегодня высшей ценностью, стал совсем другой человек - производитель и потребитель сиюминутных благ, лишенный высоких целей и идеалов, ценностная система которого отражает не духовные идеалы, а взаимные договоренности между людьми, стремящимися к приобретению мирских благ и потому находящимися в постоянном соперничестве за ограниченные земные ресурсы».

Современные дети - какие они? Нет сомнения, что современные дети отличаются от тех, которые жили 20 и 50 лет назад. Причина, конечно, в том, что они растут в совершенно другом мире. Информатизация и компьютеризация, разрыв культурных традиций, усиление внешнего контроля на фоне ослабления традиционных институтов, коммерциализация образования, поликультурность, внешняя религиозность, огромное социальное расслоение - вот реалии современного российского общества. Данные явления выступают как факторы, которые влияют на современных детей, определяют проблемы, с которыми они сталкиваются, опасности, которым они подвергаются. К ним можно отнести отчуждение от семейных связей, насилие со стороны взрослых, неограниченный доступ к информации, неготовность к диалогу в поликультурном мире. Особенное внимание стоит уделить отсутствию у современных детей четких нравственных критериев. Система ценностей современного ребенка представляет собой смешение прагматизма, индивидуализма, стремления к вещественным ценностям, поверхностным отношением к учебе, ослаблением внутреннего контроля, тягой к досугу, знанием своих прав, но не знанием обязанностей [1].

Особым разделом на Рождественских чтениях по Северобайкальской и Сосново-Озерской епархии был вопрос о воскресной школе. 
Митыпова Г. С. Образовательная среда и развитие подрастающего поколения в условиях секулярного общества (по материалам региональных Рождественских чтений «К 350-летию со дня рождения Петра I: секулярный мир и религиозность»)

В докладе Н. В. Ивановой, преподавателя воскресной школы с. Баргузин, прозвучало, что «придя в воскресную школу, ребенок попадает в атмосферу большой православной семьи, где учится овладению навыками добродетельной жизни, учится совершать добрые поступки, четко отличать добро от зла и выполнять христианские заповеди, учится умению разбираться в себе и в окружающем мире. Эта духовная воспитательная среда помогает ребенку опытно ощутить, что такое жизнь православных людей, объединенных вместе. Пробуждает жажду общения с Богом, через творческие занятия, рисование, лепку, изготовление поделок, игры, прогулки, участие в праздниках, посвященных дням Рождества Христова и Пасхи ${ }^{1}$.

Действительно, «под религиозно-церковным компонентом мы понимаем такую организацию воспитательного процесса, которая заключается в соподчинении всех сторон жизнедеятельности участников образовательных отношений религиозному началу, чем обеспечивается иерархическая направленность всего воспитательного процесса: духовное $\rightarrow$ душевное $\rightarrow$ телесное, соответствующая антропологическому устройству человека. Под семейным компонентом подразумевается то, что религиозное воспитание осуществляется при участии всей семьи и реализуется через педагогическое и душепопечительское сопровождение семей учащихся, чем обеспечивается социально-педагогическое взаимодействие всех участников воспитательного процесса (семьи, школы и церкви). Такая специфика воспитательной функции церковноприходской воскресной школы, ориентирует учащихся на непреходящие нравственные ценности, свойственные национальной культуре и способствует эффективному духовно-нравственному воспитанию. Есть надежда, что данное мероприятие поможет не только лучше узнать о страницах истории и традициях православия, но и приблизиться к подлинному пониманию смысла русской церковной истории, донести до нашего современника правду о великом подвиге народа, о царе, внесшем значительный вклад в развитие государства российского» [2, с. 146].

\section{Литература}

1. Волосова Е. Б. Взаимодействие государства и религиозных конфессий в сфере школьного образования (на примере учебного курса «Основы религиозных культур и светской этики») // Церковь, государство и общество: исторические, политико-правовые и идеологические аспекты взаимодействия: материалы международной научнопрактической конференции (Иркутск, 27 марта 2020 г.); научные редакторы И. А. Арзуманов, С. А. Комаров, А. Е. Смирнов. Москва: Межрегиональная ассоциация теоретиков государства и права, 2020. С. 84-90. Текст: непосредственный.

2. Косолапов Р. А., Косолапова Т. В. Нормативно-правовое обеспечение воспитательной функции церковно-приходской воскресной школы // Церковь, государство и общество: исторические, политико-правовые и идеологические аспекты взаимодействия: материалы международной научно-практической конференции (Иркутск, 27 марта 2020 г.); научные редакторы И. А. Арзуманов, С. А. Комаров, А. Е. Смирнов. Москва: Межрегио-

${ }^{1}$ Доклад Н. В. Ивановой. Воскресная школа для детей: современные подходы проблемы и перспективы развития // Программа Рождественских чтений «К 350-летию со дня рождения Петра I: секулярный мир и религиозность». VII Региональный этап (24 ноября 2021 г.). 
нальная ассоциация теоретиков государства и права, 2020. С. 144-154. Текст: непосредственный.

Статья поступила в редакцию 26.11.2021; одобрена после рецензирования 10.12.2021; принята к публикации 17.12.2021.

\section{EDUCATIONAL ENVIRONMENT AND DEVELOPMENT}

THE YOUNGER GENERATION IN A SECULAR SOCIETY

(based on the materials of the regional Christmas readings "On the 350th anniversary of the birth of Peter I: secular world and religiosity")

\section{Gunsema S. Mitypova}

Dr. Sci. (History), A/Prof.,

Buryat Republican Institute of Educational Policy

30 Sovetskaya St., Ulan-Ude 670000, Russia

gunsema53@mail.ru

Abstract. The article discusses the fundamental issues of spiritual and moral education in the educational environment in the context of the development of the younger generation in a secular society. The author in the article supports the position of the hierarchs of the Church that the world and man have changed today, whose value orientation is mainly aimed at the consumption of material goods. Combining efforts in the modern secular world of the clergy, the parent and teacher community will allow the development and formation of clear moral criteria and guidelines for modern children. The teaching community sets in its daily activities the tasks of the need to combine education and upbringing into a holistic educational process based on the spiritual, moral and socio-cultural values of the peoples of Russia.

Keywords: bishop, teacher, school, education, environment, upbringing, religious culture, secular world, empire, society, generation.

\section{For citation}

Mitypova G. S. Educational Environment and Development the Younger Generation in a Secular Society (based on the Materials of the Regional Christmas Readings "On the 350th Anniversary of the Birth of Peter I: Secular World and Religiosity"). Bulletin of Buryat State University. Humanities Research of Inner Asia. 2021; 4: 33-38 (In Russ.).

The article was submitted 26.11.2021; approved after reviewing 10.12.2021; accepted for publication 17.12.2021. 